\title{
XXIV. Communication on Water-pressure Engines
}

\section{Mr. John Taylor}

To cite this article: Mr. John Taylor (1811) XXIV. Communication on Water-pressure Engines, Philosophical Magazine Series 1, 37:154, 129-131, DOI: 10.1080/14786441108563254

To link to this article: http://dx.doi.org/10.1080/14786441108563254

$$
\text { 册 Published online: } 18 \text { May } 2009 .
$$

Submit your article to this journal 준

LII Article views: 3

Q View related articles ¿ 
ing you the lengths of strings, vibrations and beats, of the irregular douzeave system of the Rev. William Hawke, which has been treated of, or referred to, in four places in your Magazine (viz. vol. xxvi. p. 171, vol. xxviii. p. 304, vol. $x \times x$. p. 5, and vol. xxxvi, p. 47), without these important particulars having been published; the last of which, the beats, are particularly useful in showing the proportionate effect or aunoyance which the ear will rer eive from every false concord in the scale; at the same time that they furnish an almost infinite number of ways of tuning this system, or of checking the tuning as it proceeds.

$$
\begin{aligned}
& \text { I am, sir, } \\
& \text { Your obedient servant, }
\end{aligned}
$$

London, Feb. 9, 1811.

J. B.

\begin{tabular}{|c|c|c|c|c|c|c|c|c|}
\hline 1. & s. & 3. & 4. & 5. & 6. & $7 \cdot$ & 8. & 9. \\
\hline C & $.5000 \cdot 000$ & 480. & & & & & & \\
\hline$B$ & $-533.3 \times 338$ & 450. & $13 \cdot 377$ & 36.891 & $4 \cdot 478$ & 3.350 & 8.933 & $16 \cdot 893$ \\
\hline $\mathrm{b}_{\mathrm{B}}$ & $\cdot 5597 \cdot 118$ & $428-7922$ & $54 \cdot 049$ & $5 \cdot 393$ & & $3 \cdot 19 z$ & 63.712 & $10 \cdot 680$ \\
\hline A & $\cdot 5970 \cdot 259$ & $400 \cdot 9925$ & i 1.956 & 5.000 & 4.000 & 2.998 & $7 \cdot 981$ & $10 \cdot 012$ \\
\hline G & $.6354 \cdot 47 j^{8}$ & $377 \cdot 8055$ & $16 \cdot 833$ & 30.972 & - & 10.029 & 14.981 & $85 \cdot 748$ \\
\hline G & $\cdot 6683 \cdot 250$ & $359 \cdot 1066$ & 10.680 & $4 \cdot 466$ & 3.573 & $2 \cdot 674$ & 14.240 & 8.944 \\
\hline$F$ & .7128 .801 & 36.6625 & 10.012 & 31.856 & $3 \cdot 350$ & $2 \cdot 506$ & $6 \cdot 688$ & 31.856 \\
\hline $\mathbf{F}$ & & $320-7960$ & $35 \cdot 748$ & 3.990 & $3 \cdot 192$ & $\$ .388$ & $47 \cdot 664 \mid$ & $7 \cdot 990$ \\
\hline E & 7980.149 & 300.7463 & 8.944 & $7 \cdot 491$ & 2.099 & 2.299 & 5.970 & $7 \cdot 491$ \\
\hline $\mathrm{bE}_{\mathrm{E}}$ & $.8395 \cdot 679$ & $245.86[4$ & 31.856 & $7 \cdot 120$ & 10.029 & & 86.891 & 10.693 \\
\hline $\mathbf{D}$ & $.8938 \cdot 168$ & $268 \cdot 6683$ & $7 \cdot 990$ & $3 \cdot 3+1$ & 2.674 & 2.000 & 5.333 & 6.669 \\
\hline \# & & 251.8704 & 7.491 & 23.832 & $2 \cdot 506$ & & 5.000 & 27.024 \\
\hline $\mathbf{C}$ & $1.0000 \cdot(100$ & 240 & $10 \cdot 693$ & 2.985 & 2.988 & $1 \cdot 787$ & 30.972 & $5 \cdot 978$ \\
\hline \multirow{2}{*}{ 离 } & \multirow{2}{*}{$\begin{array}{l}\text { Lengths } \\
\text { of } \\
\text { Strings. }\end{array}$} & \multirow{2}{*}{$\begin{array}{c}\text { Vibra- } \\
\text { tion in } \\
1 \text { s }\end{array}$} & $68 \mathrm{~d}$. & |xilyd. & *4th. & 6Vth. & b6th. & VIth \\
\hline & & & \\
\hline
\end{tabular}

Table of Beats.

The beatings are all flat or sharp, as expressed in the titles at the bottom of each column, except the $4 \mathrm{Hh}$ on $b E$, and the Vth on $* \mathrm{G}$, which are otherwise expressed.

XXIV. Communication on Water-Pressure Engines. By Mr. John TaYLoR.

\section{To Mr. Tilloch.}

Sir, $I_{N}$ your Magazine for January, I have just seen the remark of Mr. John Farey on a passage in a former Number relative to an improvernent of mine in Water-pressure Engines. He conceives that he has discovered a mistake in Vol. 37. No. 154. Fel. 1811 . 
the statement, and quotes an example to prove it. It appears to me that the only mistake in the paragraph alluded to is this : that a relative term is made use of instead of a positive one, and that therefore it may be variously applied by different persons, according to the standards by which they form their comparison of size. Mr. Farey may have been in the habit of viewing small engines; while, in Cornwall and this part of Devon, we are surrounded by large ones.

He says that the author of that paragraph has made a mistake, when, speaking of Water-pressure Engines, he states that " none bave yet been successfully made upon a large scale," because, as he says, Mr. Trevithick erected one in Derbyshire, which, by a fall of $\mathbf{1 4 4}$ feet, pumped the water from a mine 48 feet below the sough.

Now, if $\mathrm{Mr}$. Farey and myself were severally to describe this engine as to its magnitude, judging by the effect as he relates it, I apprehend that each of us would appear to another person to make mistakes; for I conceive that he would speak of it as being on " a larye scale," and I should certainly call it one on a small scale.

As the quantity of water raised by the engine is not stated, it is possible that it may be somewhat larger than I conceive it to be by the only means he has afforded me of forming any kind of judgement; namely, the depth of 48 feet. But unless the volume discharged by the pumps is indeed much greater than generally occurs in mines at this depth, I should not call an engine which pumps water 48 feet, or indeed almost as many fathoms, one on a large scale.

There are pressure engines in Cornwall of a larger size probably than the one Mr. Farey mentions, on Mr. Trevithick's plan, I believe, as well as on other constructions, and with cylinders of a ceriain diameter they answer extremely well on the whole. But pressure engines have been generally objected to, by those who have seen most of them, when an attempt has been made to adipt them for copious streams, on account of the difficulties in the action of the pistons, which serve for valves, where a large aperture for waterway is required.

Having purchased one some time since, for a mine under my management, of a size which I conceive must be larger than the one in Derbyshire, and than any other I ever heard of, I found the inconveniences in its action which were apprehended, and it was to remedy these inconveniences that I endeavoured to contrive a new construction 
for the valves. I beliere that I have succeeded in doing what I wished, and that the valve which I have invented for the purpose will render it possible to erect engines of this sort for large streams of water, and consequently with cylinders of large diameters, which may act as well as those formerly erected have done with small streams applied with considerable falls.

I have as high a respect for the talents of Mr. Trevithick as Mr. Farey can have, and admire the ingenuity displayed by him in the construction of his pressure engines, as well as in other instances. I believe that the merit of bringing this kind of engine to a considerable degree of perfuction may be ascribed to him: but I apprehend he only recommended them in cases where a small stream might be applied with a considerable fall.

It may, however, often occur in certain situations, that it should be desirable to apply a copious stream where the fall may be greater than any overshot wheel can well be built for, or where wheels cannot conveniently be placed: in such circumstances I think my engine would be a useful one.

I shall, however, speak with more confidence on the subject when its merits shall have been more fully tried. Perhaps I may at a future time trouble you with some remarks on the action of this engine, and then Mr. Farey will bave an opportunity of comparing it with those which he has seen.

Holwell, near Tavistock, I am, sir, Your most obedient servant, Feb. 5,1811 . J. TAYLOR.

XXV. On the Orlits of the nexhy discovered Planets. By Mr. Firminger, late Assistant at the Royal Olservatory, Greenwich.

Since the discovery of the four small planets Ceres, Pallas, Vesta, and Juno, little seems to have been known in this country respecting their situations. The astronomers on the continent, however, have been more successful, and have not only kept up a constant series of observations on these small bodies, but have, with that indefatigable labour arid address in the application of mathematics to every department of science, for which they are so peculiarly eminent, availed themselves of every opportunity to improve I 2 